\section{ORIGINAL PAPER}

doi: 10.5455/medarh.2016.70.408-412

Med Arch. 2016 Dec; 70(6): 408-412

Received: OCT 15, 2016 | Accepted: DEC 15, 2016

(c) 2016 Edo Hasanbegovic, Nermana

Cengic, Snijezana Hasanbegovic,

Jasmina Heljic, Ismail Lutolli, Edin Begic

This is an Open Access article distributed under the terms of the Creative Commons Attribution Non-Commercial License (http://creativecommons.org/licenses/ by-nc/4.0/) which permits unrestricted non-commercial use, distribution, and reproduction in any medium, provided the original work is properly cited.

\title{
Evaluation and Treatment of Anemia in Premature Infants
}

\author{
Edo Hasanbegovic', Nermana Cengic', Snijezana \\ Hasanbegovic', Jasmina Heljic', Ismail Lutolli', Edin Begic ${ }^{2}$ \\ 'Pediatric Clinic, University Clinical Center Sarajevo, Sarajevo, Bosnia and Herzegovina \\ ${ }^{2}$ Faculty of Medicine, Sarajevo School of Science and Technology, Sarajevo, Bosnia and \\ Herzegovina
}

Corresponding author: Edo Hasanbegovic, MD, PhD, Pediatric Clinic, University Clinical Center Sarajevo, Sarajevo, Bosnia and Herzegovina. mail: hasanbegovic.edo@gmail.com.

\section{ABSTRACT}

Introduction: Anemia in preterm infants is the pathophysiological process with greater and more rapid decline in hemoglobin compared to the physiological anemia in infants. There is a need for transfusions and administration of human recombinant erythropoietin. Aim: To determine the frequency of anemia in premature infants at the Pediatric Clinic, University Clinical Center Sarajevo, as well as parameter values in the blood count of premature infants and to explore a relationship between blood transfusions with the advent of intraventricular hemorrhage (determine treatment outcome in preterm infants). Patients and methods: Research is retrospective study and it included the period of six months in year 2014. Research included 100 patients, gestational age < 37 weeks (premature infants). Data were collected by examining the medical records of patients at the Pediatric Clinic, UCCS. Results: The first group of patients were premature infants of gestational age $\leq 32$ weeks (62/100) and the second group were premature infants of gestational age 33-37 weeks (38/100). Among the patients, $5 \%$ were boys and $46 \%$ girls. There was significant difference in birth weight and APGAR score among the groups. In the first group, there were $27.42 \%$ of deaths, while in the second group, there were only $10.53 \%$ of deaths. There was a significant difference in the length of treatment. There was a statistically significant difference in the need for transfusion among the groups. 18 patients in the first group required a transfusion, while in the second group only 3 patients. Conclusions: Preterm infants of gestational age $\leq 32$ weeks are likely candidates for blood transfusion during treatment. Preterm infants of gestational age $\leq 32$ weeks have the risk of intracranial bleeding associated with the application of blood transfusion in the first week of life.

Keywords: Anemia, preterm infants, blood transfusion.

\section{INTRODUCTION}

The World Health Organization (WHO) has defined preterm birth as delivery before 37 completed weeks of gestation (gestational age is reported in terms of completed weeks (i.e., one never rounds gestational age up, so 36 weeks and 6 days of gestation is 36 weeks and not 37 weeks of gestation)) (1). All newborns are subject to decline in hemoglobin levels in the first weeks after birth. In neonatology, this condition is often called physiological anemia of the newborn. In healthy term infants, clinical signs or symptoms of anemia are absent; this normal decline in $\mathrm{Hb}$ is referred to as "physiologic" or "early anemia of infancy" (2). It was noted that the lowest value of hemoglobin in term infants rarely fall below $100 \mathrm{~g} / \mathrm{L}$ in age from 10 to 12 weeks
(3). In contrast, anemia in preterm infants (anemia of prematurity) is the pathophysiological process with larger and faster drop in hemoglobin. Consequently, there is a need for blood transfusion and application of human recombinant erythropoietin. Generally, it is considered that at the age of 4-6 weeks, premature infants of birth weight between 1000 and 1500 grams have hemoglobin value about $80 \mathrm{~g} / \mathrm{L}$, while premature infants of birth weight less then 1000 grams have hemoglobin value about $70 \mathrm{~g} / \mathrm{L}$ (3). Preterm infants are faced with the appearance of anemia of prematurity due to several main reasons (4). The first is the shortened gestational age - when it is shorter the clinical presentation is more severe. Another reason is the underdevelopment of the hematopoietic 
system in preterm infants (2). The third, very important cause of anemia are repeated acts of taking blood for laboratory analysis.

\section{AIM}

The aim of this study was to determine the frequency of clinical manifestations of anemia in premature infants at the Pediatric Clinic, University Clinical Center Sarajevo, accompanied by a drastic drop in hemoglobin and hematocrit in the blood count and a need for treatment in high-risk groups of premature infants of gestational age below 32 weeks, compared to a group of premature infants over 32 weeks and the linkage of perinatal and neonatal risk factors with the development of anemia of prematurity as well.

\section{PATIENTS AND METHODS}

Research has been set as a retrospective analysis of the characteristics of anemia of prematurity in the period of the first six months of year 2014. The study included 100 patients, gestational age < 37 weeks (premature infants), who were admitted to, after giving birth, at the Department of Neonatal Intensive Care at the Pediatric Clinic, of Clinical Center of Sarajevo University (UCCS). Inclusion criteria in the study were: the patient is a premature infant gestational age $<37$ weeks and the patient's first admission at the Department of Neonatal Intensive Care. Exclusion criteria were no data on: gestational age of the patient, the blood count at the admission, the number of received transfusions and administration of iron therapy. Analytical and descriptive methods were used. Data were collected by examining the medical records of patients at the Pediatric Clinic, UCCS. Statistical analysis of the collected data was performed through SPSS ver. 21.0. Data obtained after statistical analysis were presented in tables and figures, using Microsoft Office Excel 2007. Statistical analysis was performed by it-test. The level of significance of $\mathrm{P}<0.05$ was considered statistically significant.

\section{RESULTS}

There were two groups of patients, the first, children of gestational age $\leq 32$ weeks, and the second, children of gestational age 33-37 weeks. In the first group there were $62 / 100$ patients $(62 \%)$, while in the second $38 / 100$ (38\%) patients. The larger number of patients in each group were males (Table 1). Data analysis demonstrated a statistically significant difference $(\mathrm{P}<0.01)$ between the two groups of patients, in terms of body weight at birth (Table 2).

\begin{tabular}{lllllll}
\hline GD (weeks) & Male & $\%$ & Female & $\%$ & Total & $\%$ \\
\hline$\leq 32$ & 34 & 54.84 & 28 & 45.16 & 62 & 100 \\
\hline $33-37$ & 20 & 52.63 & 18 & 47.37 & 38 & 100
\end{tabular}

Table 1. The gender structure of patients by the groups

\begin{tabular}{llllll}
\hline GD (weeks) & Average & SD & Min & Max & P-value \\
\hline$\leq 32$ & 1349 & 516 & 500 & 2300 & \multirow{2}{*}{$<0.01$}
\end{tabular}

Table 2. The birth weight of patients
There was a statistically significant difference between the infants of gestational age $\leq 32$ weeks and gestational age 33-37 weeks, in terms of APGAR score in the first minute $(\mathrm{P}<0.001)$, and after 5 minutes $(\mathrm{P}<0.004)$ (Table $3)$.

\begin{tabular}{llllll}
\hline GD (weeks) & Average & SD & Min & Max & P-value \\
\cline { 1 - 5 }$\leq 32$ & $6 / 7$ & $2 / 2$ & $1 / 2$ & $10 / 9$ & $<0.001 /$ \\
\cline { 1 - 5 } $33-37$ & $7 / 8$ & $2 / 1$ & $3 / 5$ & $10 / 10$ & $<0.004$ \\
\hline
\end{tabular}

Table 3. APGAR score in the first and fifth minute

In the first group, $16.13 \%$ of children were reanimated, and in the second $5.26 \%$. The statistical analysis did not show any significant difference in the number of resuscitations of children between groups. In terms of deaths, $27.42 \%$ of children in the first group had a lethal outcome, and $10.53 \%$ of children in the other. It is proved a statistically significant difference in mortality between groups $(\mathrm{P}<0.04)$.

\begin{tabular}{lllll}
\hline GD (weeks) & Resuscitation & $\%$ & Deaths & $\%$ \\
\hline$\leq 32$ & 10 & 16,13 & 17 & 27.42 \\
\hline $33-37$ & 2 & 5,26 & 4 & 10.53 \\
\hline P-value & $<0,105$ & & $<0,04$ & \\
\hline
\end{tabular}

Table 4 . The number of resuscitation and deaths

Statistical analysis demonstrated a statistically significant difference in the number of erythrocytes between groups of patients gestational age $\leq 32$ weeks, and those of gestational age 33-37 weeks (Table 5.). However, there wasn't a significant difference in the level of hemoglobin and hematocrit between the two groups (Table 6-7).

\begin{tabular}{llllll}
\hline $\begin{array}{l}\text { GD } \\
\text { (weeks) }\end{array}$ & Average & SD & Min & Max & P-value \\
\hline$\leq 32$ & $4.39 \times 10^{12}$ & 0.62 & $2.6 \times 10^{12}$ & $5.6 \times 10^{12}$ & $<0.003$ \\
\hline $33-37$ & $4.52 \times 10^{12}$ & 0.71 & $3.27 \times 10^{12}$ & $6.23 \times 10^{12}$ & \\
\hline
\end{tabular}

Table 5 . The number of erythrocytes in blood count at admission

\begin{tabular}{|c|c|c|c|c|c|}
\hline GD (weeks) & Average & SD & Min & Max & $\mathrm{P}$-value \\
\hline$\leq 32$ & $155 \mathrm{~g} / \mathrm{L}$ & 22 & $92 \mathrm{~g} / \mathrm{L}$ & $199 \mathrm{~g} / \mathrm{L}$ & \multirow{2}{*}{$<0.062$} \\
\hline $33-37$ & $167 \mathrm{~g} / \mathrm{L}$ & 28 & $113 \mathrm{~g} / \mathrm{L}$ & $230 \mathrm{~g} / \mathrm{L}$ & \\
\hline \multicolumn{6}{|c|}{ Table 6. The value of hemoglobin in blood count at admission } \\
\hline GD (weeks) & Average & SD & Min & Max & $\mathrm{P}$-value \\
\hline$\leq 32$ & $0.49 \mathrm{~L} / \mathrm{L}$ & 0.07 & $0.32 \mathrm{~L} / \mathrm{L}$ & $0.61 \mathrm{~L} / \mathrm{L}$ & \multirow{2}{*}{$-<0.318$} \\
\hline $33-37$ & $0.51 \mathrm{~L} / \mathrm{L}$ & 0.08 & $0.34 \mathrm{~L} / \mathrm{L}$ & $0.68 \mathrm{~L} / \mathrm{L}$ & \\
\hline
\end{tabular}

Table 7. The value of hematocrit in blood count at admission

Out of 62 children, 18 children gestational age $\leq 32$ weeks received a blood transfusion, while only $3 / 38$ of children gestational age 33-37 weeks needed transfusion (Table 8). Statistical analysis showed a significant difference $(P<0.01)$ between mentioned groups in terms of the need for transfusion.

\begin{tabular}{llll}
\hline GD (weeks) & Number of infants & $\%$ & P-value \\
\hline$\leq 32$ & 18 & 29.03 & $<0.01$ \\
\cline { 1 - 3 } $33-37$ & 3 & 7.9 & \\
\hline
\end{tabular}

Table 8 . The number of patients with applied blood transfusion

It is observed that the bleeding occurred in patients of gestational age $\leq 32$ weeks, and in other patients it did not occur. However, statistical analysis showed no significant difference between groups. Table 9 provides information 
about the time of administration blood transfusions to patients which had an intracranial hemorrhage. 50\% of these patients received blood transfusion in the first week of life, which is statistically significant $(P=0.000)$ in terms of association between intracranial hemorrhage and transfusion applications in the first week. However, this pattern is not sufficiently representative for the adoption of concrete conclusions, because of small number of such patients.

\begin{tabular}{lllll}
\hline $\begin{array}{l}\text { GD } \\
\text { (weeks) }\end{array}$ & Bleeding & $\begin{array}{l}\text { Blood transfu- } \\
\text { sion in the first } \\
\text { week }\end{array}$ & $\begin{array}{l}\text { Blood transfu- } \\
\text { sion in further } \\
\text { treatment }\end{array}$ & P-value \\
\hline$\leq 32$ & 10 & 5 & 5 & 0.000 \\
\hline
\end{tabular}

Table 9. The connection of bleeding with the application of blood transfusion in the first week

In the group of patients $\leq 32$ weeks of gestational age, iron is introduced into therapy on average $34^{\text {th }}$ day of life, while in second group of patients, it began on average on $32^{\text {th }}$ day (Table 10). There was no statistically significant difference between the two groups in term of iron therapy.

\begin{tabular}{llllll}
\hline $\begin{array}{l}\text { GD } \\
\text { (weeks) }\end{array}$ & $\begin{array}{l}\text { Average } \\
\text { (day) }\end{array}$ & SD & Min (day) & Max (day) & P-value \\
\hline$\leq 32$ & 34 & 11 & 18 & 60 & $<0.965$ \\
\hline $33-37$ & 32 & 5 & 26 & 35 & \\
\hline
\end{tabular}

Table 10. The beginning of iron therapy

There was a statistically significant difference ( $P$ $<0.005)$ in the length of treatment in patients of gestational age $\leq 32$ weeks and those of gestational age 33-37 weeks (Table 11).

\begin{tabular}{llll}
\hline GD (weeks) & Average (day) & SD & P-value \\
\hline$\leq 32$ & 27 & 22 & $<0,005$ \\
\hline $33-37$ & 14 & 10 & $<0$ \\
\hline
\end{tabular}

Table 11 . The length of treatment

\section{DISCUSSION}

Anemia of prematurity is the focus of clinical trials in the last decade, with still uncoordinated approach, moving from observational approach and occasional controls of hematological status, limited use of erythropoietin, to liberal or today more often, restrictive practice of transfusion of packed RBCs. Based on research conducted in recent years, protocols are established, which include in evaluation the level of hemoglobin, the level of respiratory disease and the traditional signs and symptoms of pathological anemia. In this study, the premature infants are divided into two groups based on gestational age. Premature infants of gestational age $\leq 32$ weeks ( $62 \%$ of patients) were in the first group, while premature infants of gestational age between $33-37$ weeks (38 \% of patients) were in the second group. The division is modeled on other studies, which state that the anemia of prematurity is significantly more pronounced in infants gestational age $\leq 32$ weeks, compared to the rest of preterm infants. Cassady G. and Rosenkrantz T. (5) state that a half of prematurely born children, who belong to this group, develop anemia, as it typically does not occur in children of gestational age of 33-37 weeks. In a similar way, a study by Wardrop and associates was done (6), with the difference that, they are the second group divided into two, where one did infants gestational age 33-35 weeks, and the other infants gestational age 35-37 weeks.

The birth weight was measured for all premature infants and there was a significant difference among two groups, as it was expected. In the first group average birth weight was $1.394 \mathrm{~g}$, while in the second group, it was $2.242 \mathrm{~g}$ (Table 2). This parameter was taken into account as one of the risk factors for anemia of prematurity, because there is a connection between low and very low birth weight and early occurrence of serious anemia $(2,3,7)$.

As regards APGAR score, values in the first and fifth minute were taken into account and significant statistical difference has been noticed. In the first group, average APGAR score in the first minute was 5.56 while in the fifth minute it was 6.5. In the second group, there were less variations, so the average score in the first minute was 7, while in the fifth minute it was 7.67 (Table 3).

Among 100 patients, $21 \%$ died. In the first group of patients there were $27.42 \%$ deaths, while in the second group number of deaths was significantly lower. Namely, only $10.53 \%$ of premature infants with gestational age between 33-37 weeks died. Statistical analysis has shown significant difference in terms of mortality among these groups (Table 4.). These results correlate with the results of a study by Banarjee J. and associates (7), which show a significantly higher infant mortality gestational age $\leq 32$ weeks, compared to the rest of preterm infants.

In addition, patients in the first group had, on average, a longer stay at the Pediatric Clinic in relation to another group. The average length of treatment, patients from the first group, was 27 days. Patients in the second group, on average, spent 14 days on treatment (Table 11). Hintz S. et al. (8) also indicate a significant difference in the length of treatment between infants small for gestational age and very low birth weight, compared to the rest of preterm infants. We found a statistically significant difference in length of treatment between the two groups $(\mathrm{P}<0.005)$.

Focus of the research was hematology status and blood transfusion needs. At the admission, the first and second group had approximately same values of blood count which has been changed significantly during hospitalization, meanwhile blood transfusion needs arise. So the average number of erythrocytes in the first group was $4,39 \times 10^{12}$, hemoglobin value was $155 \mathrm{~g} / \mathrm{L}$ and average hematocrit was $0,49 \mathrm{~L} / \mathrm{L}$. In the second group results were similar: average number of erythrocytes in the second group was $4,52 \times 10^{12}$, hemoglobin value was $167 \mathrm{~g} / \mathrm{L}$ and average hematocrit was $0,51 \mathrm{~L} / \mathrm{L}$. Statistical analysis has proven significant difference in number of erythrocytes among patients of gestational $\leq 32$ weeks and patients of gestational age between $33-37$ weeks $(\mathrm{P}<0,003)$. However, there was no significant difference in hemoglobin and hematocrit level among groups of patients (Table 5, 6 and 7). Banerjee J. et al. (7) did a study association of hemoglobin after birth with short-term outcome of treatment 
prematurely born infants. They proved its connection with the subsequent need for transfusions and death.

Among 100 patients, $21 \%$ required blood transfusion during the treatment. In the group of premature infants of gestational $\leq 32$ weeks, $29.03 \%$ received blood transfusion. In the second group, $7.9 \%$ of patients required blood transfusion during hospitalization at Clinic ( $\mathrm{Ta}-$ ble 8). Statistical analysis showed significant difference in blood transfusion needs among premature infants of gestational age $\leq 32$ weeks and premature infants of gestational age between 33-37 weeks. Strauss R.G. (9) states that transfusions annually receive even 300.000 premature infants, but mostly, it is about infants with very low and extremely low birth weight.

In the group of premature infants of gestational age $<32$ weeks even $29.3 \%$ received transfusion of erythrocytes, while in the group of premature infants of gestational age between 33-37 weeks, only three of them received transfusion of erythrocytes. Statistical analysis has proven significant difference $(\mathrm{P}<0,01)$ among these groups in terms of need for blood transfusion.

Zuppa and coworkers (10) worked on study about connection of gestational age and blood transfusion needs. They have proven that premature infants of gestational age $\leq 32$ weeks are the most probably candidates for blood transfusion and that is in accordance to our findings.

Interesting data was arisen during the research of connection between occurrence of intracranial bleeding and blood transfusion application. Namely, among 18 premature infants of gestational age $\leq 32$ weeks, in 10 of them intraventricular hemoragy were registered. In contrast, among 3 premature infants of gestational age between 33-37 weeks, there was no such bleeding. However, because of small number of cases, statistical analysis did not show significant difference among groups.

Due to intracranial bleeding associated with the application of transfusions in the first week of life, it is made the examination of these data in the first group of patients. Namely, Christensen R. D. (11) associated the occurrence of intracranial bleeding with early application of transfusions, indicating that the subsequent application is associated with the occurrence of necrotizing enterocolitis.

Goldber and coworkers (12) show the possibility of bleeding caused by rapid growth of intravascular volume in premature infants of gestational age $\leq 32$ weeks. And other studies confirms connection between intraventricular hemoragy and blood transfusion of deplasmated erythrocytes in premature infants $(13,14,15)$.

Among 10 patients with intracranial bleeding in the group of premature infants of gestational age $<32$ weeks, $50 \%$ of them received blood transfusion in first week of life and other $50 \%$ received blood transfusion later during hospitalization. Statistically there was significant connection ( $\mathrm{P}=0.000)$ of occurrence of intracranial bleeding and blood transfusion application in first week of life. Since intraventricular hemoragy has multifactor etiology which includes fluctuations of cerebral flow and increase of cerebral venous pressure and taking into ac- count that small number of patients were in place, this sample is not enough representative for making concrete conclusions, although surely indicates the connection noticed by other authors as well as need for further research of this connection in more relevant sample.

Finally, there were collected the data about the time of beginning the iron therapy, during the stay of patients at the Clinic. In the first group of patients, iron therapy was administered on average $34^{\text {th }}$ day of life, and in the second group on average on $32^{\text {th }}$ day. There was no statistically significant difference between the two groups in term of iron therapy (Table 10).

Meyers P. et al. (16) reported that the timely beginning of iron therapy is necessary to stimulate erythropoiesis in premature infants, since the iron depots are established in the third trimester of pregnancy, in order to avoid anemia due to iron deficiency, since it is known that anemia of prematurity does not correspond to the iron therapy.

\section{CONCLUSIONS}

Frequency of anemia with drastic fall of hemoglobin and hematocrit and need for blood transfusion in premature infants with gestational age $<32$ weeks, is 29.3 $\%$, meaning that almost every third premature infant of gestational age $<32$ weeks develops anemia requiring treatment.

There is statistically significant difference in frequency of anemia in premature infants of gestational age $<32$ weeks compared to premature infants of gestational age $>32$ weeks, meaning that level of anemia negatively correlate with gestational age.

There is a significant difference in birth weight and APGAR score between premature infants of gestational age $\leq 32$ weeks and premature infants of gestational age between 33-37 weeks, which indicates worse condition of these children at birth and more aggressive approach during laboratory analysis, which makes influence to earlier development of anemia.

There is no significant difference in the blood count of preterm infants at admission in relation to gestational age.

Premature infants of gestational age $\leq 32$ weeks due to frequent development of manifested anemia during hospitalization, more often requires blood transfusion during treatment what is statistically significant.

Premature infants of gestational age $\leq 32$ weeks have risk of occurrence of posttransfusion complications, while the most serious one among them is intracranial hemoragy connected to application of blood transfusion in first week of life.

Conflict of interest: none declared.

\section{REFERENCES}

1. Institute of Medicine (US) Committee on Understanding Premature Birth and Assuring Healthy Outcomes; Behrman RE, Butler AS, editors. Preterm Birth: Causes, Consequences, and Prevention. Washington (DC): National Academies Press (US); 2007. 2, Measurement of Fetal and Infant Maturity. Available from: https:/www.ncbi.nlm.nih.gov/books/NBK11382/ 
2. Widness JA. Pathophysiology of Anemia During the Neonatal Period, Including Anemia of Prematurity. NeoReviews. 2008; 9(11): e520. doi:10.1542/neo.9-11-e520.

3. Strauss RG. Anaemia of Prematurity: Pathophysiology \& Treatment. Blood reviews. 2010; 24(6): 221-5. doi:10.1016/j. blre.2010.08.001.

4. Jeon GW, Sin JB. Risk Factors of Transfusion in Anemia of Very Low Birth Weight Infants. Yonsei Medical Journal. 2013; 54(2): 366-73. doi:10.3349/ymj.2013.54.2.366.

5. Cassady G. Rosenkrantz T. Anemia of Prematurity, 2013; http:// emedicine.medscape.com/article/978238-overview

6. Wardrop CA, Holland BM, Veale KE, Jones JG, Gray OP. Nonphysiological anaemia of prematurity. Arch Dis Child. 1978; 53(11): 855-60.

7. Banerjee J, Asamoah KF, Singhvi D, Kwan WHA, Morris JK, Aladangady N. Haemoglobin level at birth is associated with short term outcomes and mortality in preterm infants. BMC Medicine. 2015; 13: 16. doi:10.1186/s12916-014-0247-6.

8. Hintz S, Bann CM, Ambalavanan N, Cotten CM, Das A, Higgins RD. Predicting Time to Hospital Discharge for Extremely Preterm Infants. Pediatrics. 2010; 125(1): e146-e154. doi:10.1542/peds.2009-0810.

9. Strauss RG. Transfusion therapy in neonates. Am J Dis Child. 1991; 145: 904-11.

10. Zuppa AA, Mazzotta M, Maragliano G, Girlando P, Florio MG, Tortorolo G. Anemia of prematurity: risk factors influencing red cell transfusions. Minerva Pediatr. 1995; 47(1-2): 13-8.
11. Christensen RD. Associations between "early" red blood cell transfusion and severe intraventricular hemorrhage, and between "late" red blood cell transfusion and necrotizing enterocolitis. SeminPerinatol. 2012; 36(4): 283-9. doi: 10.1053/j. semperi.2012.04.009.

12. Goldberg RN, Chung D, Goldman LS, Bancalari E. The association of rapid volume expansion and intraventricular hemorrhage in the preterm infant. Journal of Pediatrics. 1980; 96(6): 1060-3.

13. Bell EF, Strauss RG, Widness JA, Mahoney LT, Mock DM, Seward VJ, et al. Randomized Trial of Liberal Versus Restrictive Guidelines for Red Blood Cell Transfusion in Preterm Infants. Pediatrics. 2005; 115(6): 1685-91. doi:10.1542/ peds.2004-1884.

14. Baer, VL,, Henry E, Lambert DK, Stoddard RA, Wiedmeier SE, Eggert LD, et al. Implementing a program to improve compliance with neonatal intensive care unit transfusion guidelines was accompanied by a reduction in transfusion rate: a pre-post analysis within a multihospital health care system. Transfusion. 2011; 51, 264-69.

15. Bell E. When to transfuse preterm babies. Archives of disease in childhood Fetal and neonatal edition. 2008; 93(6): F469-F473. doi:10.1136/adc.2007.128819.

16. Meyers P, Huffstetler A. Anemia of Prematurity: To Transfuse or Not to Transfuse. National Association of Neonatal Nurses. 2013. 